\title{
Molecular Phylogeny and In Situ Detection of the Etiologic Agent of Necrotizing Hepatopancreatitis in Shrimp
}

\author{
JAMES K. LOY,${ }^{1 *}$ FLOYD E. DEWHIRST, ${ }^{2}$ WILLIAM WEBER, ${ }^{3}$ PAUL F. FRELIER, ${ }^{1}$ \\ THEODORE L. GARBAR, ${ }^{1}$ SERBAN I. TASCA, ${ }^{1}$ AND JOE W. TEMPLETON ${ }^{1}$ \\ Department of Veterinary Pathobiology, Texas A\&M University, College Station, Texas $77843^{1}$; \\ Department of Molecular Genetics, Forsyth Dental Center, Boston, Massachusetts 02115²; \\ and Aprogenex, Inc., Houston, Texas $77054^{3}$
}

Received 27 September 1995/Accepted 5 June 1996

\begin{abstract}
Necrotizing hepatopancreatitis (NHP) is a severe disease of farm-raised Penaeus vannamei that has been associated with mortality losses ranging from 20 to $95 \%$. NHP was first recognized in Texas in 1985 (S. K. Johnson, p. 16, in Handbook of Shrimp Diseases, 1989) and is an economically important disease that has limited the ability to culture shrimp in Texas. The putative cause of NHP is a gram-negative, pleomorphic, intracellular, rickettsia-like bacterium that remains uncultured in part because of the absence of established shrimp cell lines. The inability to culture the NHP bacterium necessitated the use of molecular methods for phylogenetic placement of the NHP bacterium. The gene encoding the 16S rRNA (16S rDNA) of this shrimp pathogen was amplified by PCR, cloned, and sequenced. Sequence analysis of the cloned 16S rDNA indicates that the NHP bacterium is a member of the $\alpha$ subclass of the Proteobacteria. Within the alpha subclass, the NHP bacterium is shown to be most closely related to bacterial endosymbionts of protozoa, Caedibacter caryophila and Holospora obtusa. Also, the NHP bacterium is distinct from but related to members of the typhus group (Rickettsia typhi and $R$. prowazekii) and spotted fever group (R. rickettsii) of the family Rickettsiaceae. Fluorescently labeled oligonucleotide DNA probes that bind to variable regions (V2, V6, and V8) of 16S rRNA of the NHP bacterium were used to detect the bacterium in infected shrimp by in situ hybridization. This technique provided direct visual evidence that the 16S rDNA that was amplified, cloned, and sequenced was derived from the intracellular bacterium that infects the hepatopancreas of farm-raised $P$. vannamei shrimp.
\end{abstract}

A novel intracellular bacterium is associated with a severe disease of farm-raised Pacific white shrimp, Penaeus vannamei. This disease is most commonly referred to as necrotizing hepatopancreatitis (NHP); however, synonyms for NHP include the Texas pond mortality syndrome and granulomatous hepatopancreatitis $(14,24)$. NHP is an economically important disease that has severely limited shrimp production in Texas and has recently been diagnosed in Central and South America. The putative cause of NHP is a gram-negative, pleomorphic, intracellular, rickettsia-like bacterium that resides and multiplies in tubular epithelial cells of the hepatopancreas of infected shrimp.

Morphologic studies of NHP describe two or three distinct bacterial forms within the cytoplasm of infected hepatopancreatic tubular epithelial cells $(14,21,24)$. Although multiple morphologically distinct organisms have been associated with NHP, these organisms are thought to represent different morphologic forms of a single, complex bacterium (24). The most prevalent form of the NHP bacterium is a small, pleomorphic, gram-negative coccobacillus that morphologically resembles members of the order Rickettsiales. This form of the bacterium is round (averaging $0.32 \mu \mathrm{m}$ in diameter) to rod shaped and exhibits a trilaminar cytoplasmic membrane with an undulating, outer envelope. The rod-shaped form of the bacterium is 0.59 to $1.18 \mu \mathrm{m}$ long and $0.36 \mu \mathrm{m}$ wide. Occasionally, rodshaped bacterial forms exhibit a transverse, centralized annular constriction, indicating that this form replicates by binary fission (14). The other distinct morphologic form of the bacte-

\footnotetext{
* Corresponding author. Present address: Department of Experimental Pathology, Bristol-Myers Squibb, P.O. Box 4000, F14-03, Princeton, NJ 08543. Phone: (609) 252-5071. Fax: (609) 252-6609.
}

rium is a long helical rod that exhibits a tapered profile with prominent helical ridges at the apical pole and numerous lucent vacuoles in the blunted, basilar aspect of the organism. This less common, helical form of the NHP bacterium contains eight, long periplasmic flagella arising from the basilar aspect of the organism that have not been identified in the replicative form (24). The helical form of the NHP bacterium averages $0.24 \mu \mathrm{m}$ in width and can exceed $3.25 \mu \mathrm{m}$ in length $(14,21,24)$. An indistinct, intermediate form that exhibits morphologic characteristics common to both the replicative and helical forms is occasionally identified in infected hepatopancreatic epithelial cells. This intermediate form is an elongated rodshaped organism that exhibits a curved to undulating profile and contains varying numbers of lucent protoplasmic vacuoles that are clustered at one end of the organism. Progressive morphologic changes in the intermediate form suggest a maturation sequence from the replicative form toward the helical form. During this metamorphosis, the intermediate form acquires a tapered profile with a distinct, blunted basilar aspect and a pointed apical aspect (24).

Attempts to culture the NHP bacterium have been unsuccessful, in part because of the absence of established shrimp cell culture systems (13). However, the rod-shaped form of the NHP bacterium has been purified by Percoll density gradient ultracentrifugation and NHP has been reproduced by injection of this enriched bacterial isolate into the hepatopancreas of normal $P$. vannamei shrimp. This experimental reproduction of NHP served to demonstrate that the intracellular bacterium is the causative agent of NHP and indicates that the rod-shaped form of the bacterium plays a dominant role in the pathogenesis of the disease (14).

This rickettsia-like NHP bacterium still remains uncultured, and its taxonomic classification is uncertain. The systematic 
evaluation of nucleic acid sequences has enabled the construction of phylogenetic schemes for diverse prokaryotic and eukaryotic organisms $(10,12)$. The $16 \mathrm{~S}$ rRNA sequence and the gene that encodes the 16S rRNA (16S rDNA) are used for phylogenetic classification of bacteria $(7,8,26,27,42)$ and are especially useful in the taxonomic classification of uncultured or fastidious bacteria $(20,30,38,41)$. The utility of the ribosomal subunit for the phylogenetic classification is based on its universal distribution, consistency of function, conserved primary sequence with low rate of change, and ease of isolation (12). In this study, the $16 \mathrm{~S}$ rDNA of a Percoll-purified isolate of the NHP bacterium was amplified by PCR, cloned into a pSP65 vector, and sequenced to enable phylogenetic classification of the NHP bacterium.

In situ hybridization with fluorescent oligonucleotide probes has been used to provide phylogenetic classification of bacteria and can be used to distinguish bacterial species within related genomic groups $(2-4,6,35)$. In the present study, the NHP bacterium was confirmed to be the source of the amplified, cloned, and sequenced 16S rDNA by in situ hybridization. The $16 \mathrm{~S}$ rDNA sequence obtained during phylogenetic classification of the NHP bacterium was analyzed and specific oligonucleotide probes designed to hybridize to variable regions (V2, V6, and V8) of the 16S rRNA of the NHP bacterium were identified and tested. In situ hybridization showed that fluorochrome-labeled oligonucleotide probes localized to the cytoplasm of hepatopancreatic tubular epithelial cells of NHPinfected $P$. vannamei shrimp, thereby authenticating the NHP bacterium as the source of the $16 \mathrm{~S}$ rDNA sequence.

\section{MATERIALS AND METHODS}

Bacterial isolate and extraction of bacterial DNA. The rod-shaped form of the NHP bacterium was isolated from shrimp hepatopancreata obtained during a spontaneous outbreak of NHP in cultured $P$. vannamei in Texas. The NHP bacteria were purified from the shrimp tissue by a modified Percoll (Pharmacia LKB, Pleasant Hill, Calif.) density gradient centrifugation as described previously $(13,37)$. Briefly, 8 to 10 chilled hepatopancreata were macerated and centrifuged at $200 \times g$ for $8 \mathrm{~min}$ in Tris-sucrose buffer $(\mathrm{pH} 7.4)$, containing 0.033 $\mathrm{M}$ Tris-hydrochloride and $0.25 \mathrm{M}$ sucrose, to remove tissue debris. The supernatant was removed, layered on Percoll at a final concentration of $40 \%$, and centrifuged at $25,000 \times g$ for $60 \mathrm{~min}$ in an ultracentrifuge. A band of bacteria, formed at the interface of the Percoll, was harvested and frozen in aliquots at $-70^{\circ} \mathrm{C}$. Smears of the harvested band were stained with Gram stain, and a pellet derived from the harvested band was examined by electron microscopy to confirm the presence of the NHP bacterium (13). DNA was then extracted from two separate Percoll-purified isolates of the NHP bacterium. Briefly, $25 \mathrm{mg}$ of the Percoll-purified bacterial isolate was suspended in $250 \mu$ l of digestion buffer ( 50 $\mathrm{mM}$ Tris, $20 \mathrm{mM}$ EDTA, $0.5 \%$ sodium dodecyl sulfate [pH 8.5]) in $0.5-\mathrm{ml}$ Eppendorf tubes. Proteinase K $(7.5 \mu \mathrm{l}$ of a $20-\mathrm{mg} / \mathrm{ml}$ stock solution) was added to each tube, and the solution was incubated at $60^{\circ} \mathrm{C}$ for $2 \mathrm{~h}$ with periodic vortexing of reactants; this was followed by heat inactivation of proteinase $\mathrm{K}$ at $95^{\circ} \mathrm{C}$ for $10 \mathrm{~min}$. The tubes were then microcentrifuged for $3 \mathrm{~min}$ at $13,000 \mathrm{rpm}$, and $75 \mu \mathrm{l}$ of the supernatant was applied to a CHROMA SPIN TE-100 (Clontech Laboratories, Palo Alto, Calif.) column and centrifuged in a horizontal rotor as specified by the manufacturer. The eluent collected by centrifugation was diluted 1:100 and 1:1,000 in distilled water (Gibco-BRL, Grand Island, N.Y.) prior to use in the PCR amplification of $16 \mathrm{~S}$ rDNA.

PCR. The 16S rDNA of the NHP bacterium was amplified by PCR with slight modifications of primers described by Weisburg et al. (38). The primers are designed to target the $16 \mathrm{~S}$ rDNA with near-full-length replication of the $16 \mathrm{~S}$ rDNA (approximately 1,500 bases). The $5^{\prime}$ and $3^{\prime}$ PCR primers incorporate a HindIII restriction site and an EcoRI restriction site, respectively, to facilitate insertion into a plasmid cloning vector. The sequence of the forward primer is 5'GCAAGCTTAGAGTTTGATCCTGGCTCA (Escherichia coli positions 8 to 26), and the sequence of the reverse primer is 5'GCGAATTCACGGCTACC TTG TTACGACTT (E. coli positions 1492 to 1512). The HindIII restriction site in the forward primer and the EcoRI restriction site in the reverse primer are underlined. PCR was performed with $50-\mu l$ reaction mixtures containing $10 \mathrm{mM}$ Tris- $\mathrm{HCl}$ ( $\mathrm{pH} 8.3$ ), $50 \mathrm{mM} \mathrm{KCl}, 1.5 \mathrm{mM} \mathrm{MgCl}, 200 \mathrm{mM}$ deoxynucleotides, 0.5 $\mu \mathrm{M}$ (each) forward and paired reverse primers, $1.25 \mathrm{U}$ of AmpliTaq DNA polymerase (Perkin-Elmer Cetus Instruments, Norwalk, Conn.), and 0.03 to 0.3 $\mu \mathrm{g}$ of template DNA $(2.5 \mu \mathrm{l}$ of the column-purified DNA previously diluted 1:100 or 1:1,000 in distilled water). The final solution was then overlaid with mineral oil. The amplification profile consisted of 30 cycles of $45 \mathrm{~s}$ at $92^{\circ} \mathrm{C}, 45 \mathrm{~s}$
TABLE 1. Sequencing primers and approximate locations in the 16S rRNA sequence of $E$. coli

\begin{tabular}{llc}
\hline \multicolumn{1}{c}{$\begin{array}{c}\text { Primer } \\
\text { name }\end{array}$} & \multicolumn{1}{c}{$\begin{array}{c}\text { Primer } \\
\text { sequence }\end{array}$} & $\begin{array}{c}\text { Location } \\
\text { (E. coli })\end{array}$ \\
\hline Primer 1187 & 5'-TCACACAGGAAACAGCTATG-3' & $-{ }^{a}$ \\
fs-1 & 5'-GACGATAATGACGGTAGCAG-3' & $474-499$ \\
fs-2 & 5'-GGAGCAAACAGGTTAGA-3' & $775-792$ \\
fs-3 & 5'-GGGACAGAAGGCTCAG-3' & $998-1014$ \\
fs-4 & 5'-CTTATGGGCTGGGCTACACA-3' & $1011-1029$ \\
Primer A & 5'-ATTTAGGTGACACTATA-3' & $-{ }^{a}$ \\
rs-1 & 5'-TGTGTAGCCCAGCCCATAAG-3' & $1211-1228$ \\
rs-2 & 5'-CATCGTTTACGGCGTGGA-3' & $807-820$ \\
rs-3 & 5'-GGGCTTTCACACCTTGCTTA-3' & $613-595$ \\
rs-4 & 5'-CTACCGTCATTATCGTCACA-3' & $445-459$ \\
rs-5 & 5'-AGGTAGATTCCCGTGTATTA-3' & $119-138$ \\
\hline
\end{tabular}

${ }^{a}$ Sequencing primer in cloning vector.

at $52^{\circ} \mathrm{C}$, and $2 \mathrm{~m}$ at $72^{\circ} \mathrm{C}$ with an additional $8 \mathrm{~min}$ at $72^{\circ} \mathrm{C}$ following the final cycle. A $10-\mu \mathrm{l}$ aliquot of each PCR product was examined by electrophoresis in $1 \%$ agarose in Tris-acetate-EDTA (TAE) buffer containing $1 \mu \mathrm{g}$ of ethidium bromide per $\mathrm{ml}$.

Cloning and sequencing of PCR products. The PCR products were purified by electrophoresis ( $50 \mathrm{~V}$ for 5 to 6 hours) in a $1.5 \%$ agarose gel to removed unincorporated primers and incomplete PCR extension products. Following electrophoresis, the bands containing PCR products were excised from the agarose gel and the DNA was extracted from the gel matrix with the Qiaex DNA ge extraction kit, as recommended by the manufacturer (Qiagen, Studio City, Calif.). The PCR products were then were incubated with HindIII and EcoRI (Boehringer Mannheim) as recommended by the manufacturer and ligated to a similarly prepared pSP65 vector (Promega, Madison, Wis.) in preparation for cloning in Epicuran coli SCS1 competent cells (Stratagene, La Jolla, Calif.) Following transformation and selection of clones, plasmids were extracted from the transformed cells with P20 columns (Qiagen, Chatsworth, Calif.) as recommended by the manufacturer and resuspended in $100 \mu \mathrm{l}$ of TE buffer. The plasmids were screened for the PCR insert by HindIII and EcoRI digestion of a $2-\mu l$ fraction of each plasmid solution followed by agarose gel electrophoresis of the product. Ten cloned plasmids that contained an appropriate-size insert were monitored by chain termination DNA sequencing with the DNA Sequenase ki (United States Biochemical, Cleveland, Ohio) as recommended by the manufacturer. Initially, the first 200 bases of each DNA strand from the inserts of 10 clones was sequenced, and no mismatches were identified. Seven clones were derived from one sample of bacteria, and three clones were derived from the other bacterial sample. Since the first 200 bases of either strand of the $16 \mathrm{~S}$ rDNA includes recognized variable regions, the clones were considered equivalent Subsequently, six clones were chosen and sequenced completely. The sequencing primers and their approximate location in the 16S rDNA (E. coli numbers) are listed in Table 1.

16S rRNA data analysis. The sequenced $16 \mathrm{~S}$ rDNA was compared with all sequence data maintained in GenBank and EMBL databases by using the BLAST algorithm to ensure that the origin of the sequence was 16S rDNA and that the sequence was unique (1). For phylogenetic analysis, a program set for data entry, editing, sequence alignment, secondary-structure comparison, similarity matrix generation, and dendrogram construction for 16S rRNA data was written in Microsoft QuickBASIC for use on IBM PC and compatible computers (28). The sequence database contains approximately 500 sequences determined in the laboratory of F. E. Dewhirst and another 200 obtained from GenBank or the Ribosomal Database Project $(7,8,28)$. Similarity matrices were constructed from the aligned sequences by using only positions for which $90 \%$ of the strains had data. The similarity matrices were corrected for multiple base changes by the method of Jukes and Cantor (18). Phylogenetic trees were constructed by the neighbor-joining method of Saitou and Nei (31). Bootstrapping of neighbor-

TABLE 2. Sequence of the fluorescence-labeled probes ${ }^{a}$

\begin{tabular}{llc}
\hline $\begin{array}{l}\text { Probe } \\
\text { name }\end{array}$ & \multicolumn{1}{c}{ Probe sequence } & $\begin{array}{c}\text { Location } \\
\text { (E. coli })\end{array}$ \\
\hline prV2 & 5'-AGGTAGATTCCCGTGTATTA-3' $^{\prime}$ & $151-171$ \\
prV6 & $5^{\prime}$-TCTGATGCCTCCTGTCCCTAT-3' & $997-1018$ \\
prV8 & $5^{\prime}$-TCACCCCCTTGCTTCTCATTGT-3' & $1249-1271$ \\
NS & $5^{\prime}$-ATTCCTTACTGCTGCCTCCCGTAGGAGTTT-3' & $338-367$ \\
\hline
\end{tabular}

${ }^{a}$ The approximate location of each probe (in E. coli numbers) is given. 
(\% Difference)

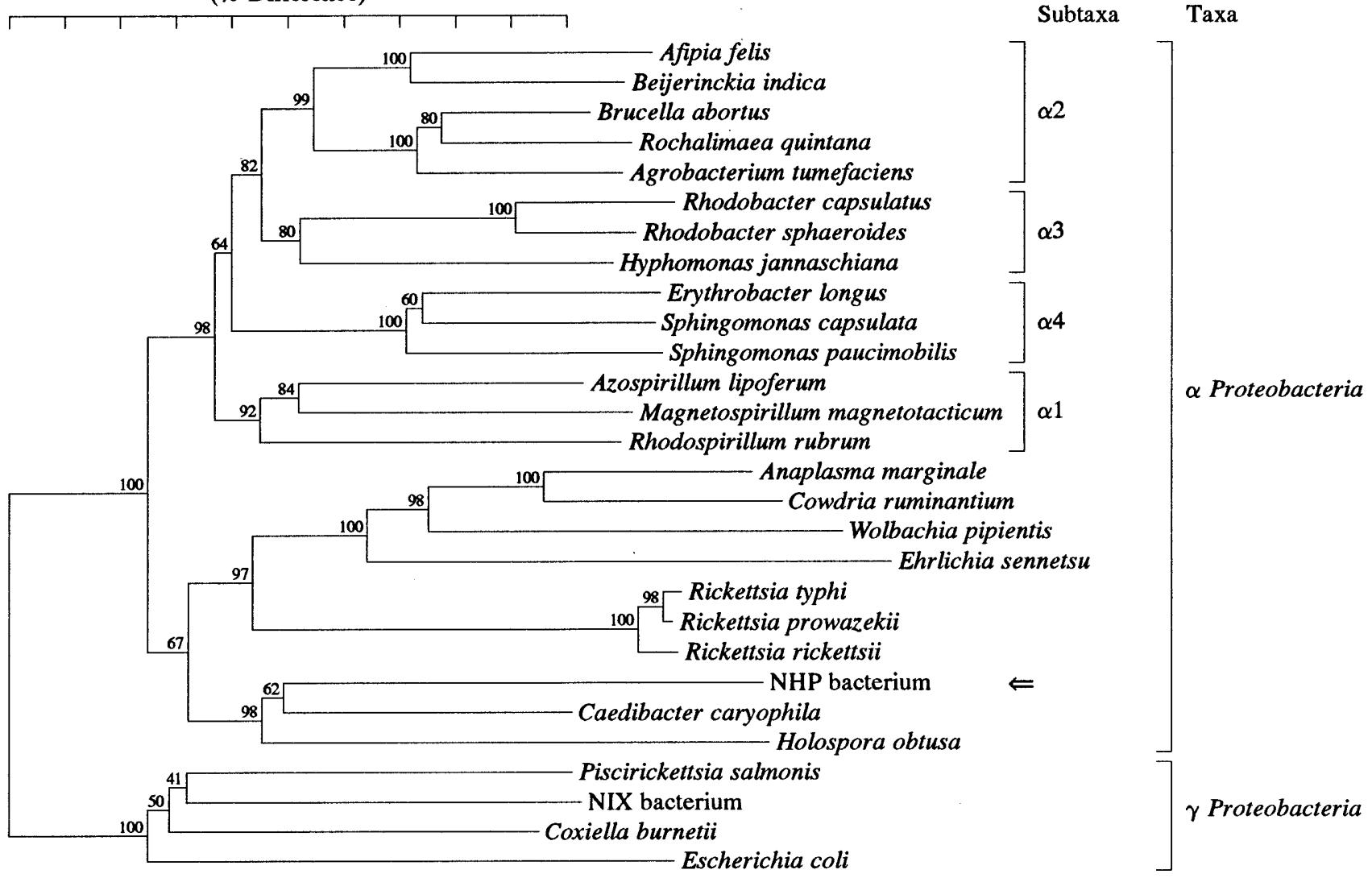

FIG. 1. Phylogenetic tree comparing the NHP bacterium with various members of the $\alpha$ - and $\gamma$-Proteobacteria. The number at the branch points depicts the percent occurrence of a given branch during 500 resamplings of the bootstrap analysis.

joining trees was performed with the program MEGA (22), with 500 resamplings and pairwise elimination of incomplete data.

rRNA probe design and synthesis. Computer-assisted analysis of the $16 \mathrm{~S}$ rDNA sequence revealed three nucleic acid sequence segments that were unique to the NHP bacterium (Table 2). The sequences (prV2, prV6, and prV8) range from 18 to 22 nucleotides and are derived from recognized variable regions (V2, V6, and V8, respectively) of the 16S rDNA sequence. A universal eubacterial 16S probe served as a positive control (19). For each sequence, duplicate probes that were conjugated to either fluorescein isothiocyanate or a fluorescent rhodamine derivative (Texas red; Clonetech) were manufactured. Oligonucleotide probes were synthesized (Applied Biosystems DNA synthesizer model $380 \mathrm{~B}$ ), and the fluorochrome label was conjugated to an aminoethyl phosphate linker (Aminolink I; Applied Biosystems) incorporated at the 5' end of the oligonucleotide. The probes were purified by Waters high-pressure liquid chromatography with a baseline 810 chromatography workstation.

Tissue section preparation and probe hybridization conditions. Infected $P$. vannamei shrimp were obtained during a natural outbreak of NHP in Texas. The hepatopancreata of live specimens were given injections of Davidson's fixative (16), the shrimp were dissected, and the organ was removed from each shrimp. The hepatopancreas was immersed in Davidson's fixative for $24 \mathrm{~h}$, transferred to $70 \%$ ethanol, and processed for routine histologic examination. Paraffin-embedded specimens were sectioned at 3 to $4 \mu \mathrm{m}$ and mounted on positively charged slides (Fisher Scientific, Pittsburgh, Pa.). The sections were deparaffinized by being heated at $65^{\circ} \mathrm{C}$ for $20 \mathrm{~min}$ and then being immersed in xylenes for 2 min, with three changes of xylene. The slides were rehydrated by immersion for $1 \mathrm{~min}$ in each of the following graded ethanol solutions: absolute, $95 \%, 75 \%, 50 \%$, and finally distilled water. The slides were then immersed for $15 \mathrm{~min}$ in phosphatebuffered saline (PBS) $\left(137 \mathrm{mM} \mathrm{NaCl}, 2.7 \mathrm{mM} \mathrm{KCl}, 4.3 \mathrm{mM} \mathrm{NaH} \mathrm{PO}_{4} \cdot 7 \mathrm{H}_{2} \mathrm{O}\right.$, $1.4 \mathrm{mM} \mathrm{KH}_{2} \mathrm{PO}_{4}\left[\mathrm{pH} \mathrm{7.3])}\right.$ at $45^{\circ} \mathrm{C}$ and incubated in a proteinase $\mathrm{K}$ solution (100 $\mu \mathrm{g} / \mathrm{ml}$ in PBS) for $15 \mathrm{~min}$ at $37^{\circ} \mathrm{C}$. The slides were equilibrated with $1.6 \mathrm{mM}$ dithiothreitol (Boehringer Mannheim) in PBS for $10 \mathrm{~min}$ at $45^{\circ} \mathrm{C}$ and blocked with $1.6 \mathrm{mM}$ dithiothreitol-1.6 $\mathrm{mM}$ iodoacetemide (Aldrich Chemical, Milwaukee, Wis.) $1.59 \mathrm{mM} \mathrm{N}$-ethylmaleimide (Sigma, St. Louis, Mo.) in PBS for $30 \mathrm{~min}$ at $45^{\circ} \mathrm{C}$. The slides were rinsed twice for $5 \mathrm{~min}$ in PBS at room temperature (RT; $\left.25^{\circ} \mathrm{C}\right)$ and equilibrated in $1.75 \%$ triethanolamine (TEA; Sigma) $(\mathrm{pH} 8.0)$ at RT. The slides were transferred to fresh TEA- $0.25 \%$ acetic anhydride (Sigma) for 5 min at RT and then transferred to TEA- $0.5 \%$ acetic anhydride for 5 min at RT. The slides were blocked in $2 \times \mathrm{SSC}(1 \times \mathrm{SSC}$ is $0.15 \mathrm{M} \mathrm{NaCl}$ plus $0.015 \mathrm{M}$ sodium citrate) for $5 \mathrm{~min}$ at RT and then immersed in distilled $\mathrm{H}_{2} \mathrm{O}$ for $5 \mathrm{~min}$ at RT. The probes were diluted in hybridization cocktail (Aprogenex Inc., Houston, Tex.) and 30 to $50 \mu \mathrm{l}$ of this solution was applied to the slide. A concentration of 0.04 $\mu \mathrm{g} / \mu \mathrm{l}$ was used for probes labeled with fluorescein isothiocyanate, and a concentration of $0.02 \mu \mathrm{g} / \mathrm{ml}$ was used for probes labeled with Texas red. Coverslips were placed over the slides, and the slides were incubated in a humid chamber at $42^{\circ} \mathrm{C}$ for $10 \mathrm{~min}$ and then transferred for $45 \mathrm{~s}$ to a prewarmed hotplate set at $92^{\circ} \mathrm{C}$. The slides were returned to the humid chamber and incubated for 5 to 16 hours at $42^{\circ} \mathrm{C}$ in the dark. Following hybridization, the slides were washed in Aprogenex Wash A at $42^{\circ} \mathrm{C}$ for $15 \mathrm{~min}$ and transferred to Aprogenex Wash B at RT for 10 min with two changes. The slides were mounted in either propidium iodide/Antifade (Oncor) or Vectashield (Vector Laboratories, Inc., Burlingame, Calif.) and viewed on an Olympus BH10 microscope equipped with fluorescence capabilities. Photomicrographs were taken with Kodak Ektachrome EES-135 (PS 1600) film and push processed at 1,600 ASA.

Nucleotide sequence accession numbers. The sequences of the bacterial strains are maintained in EMBL, GenBank and Ribosomal Data Base Project nucleotide sequence databases and are available by electronic retrieval. The accession numbers of the bacterial sequences in the GenBank database are as follows: Afipia felis, M65248; Agrobacterium tumefaciens, M11223; Anaplasma marginale, M60313; Azospirillum lipoferum, Z29619; Beijerinckia indica M59060; Brucella abortus, X13695; Caedibacter caryophila, X71837; Cowdria ruminantium, X61659; Coxiella burnetii, M21291; Ehrlichia sennetsu, M73225; Erythrobacter longus, M59062; Escherichia coli, J01695; Hyphomonas jannaschiana, M83806; Magnetospirillum magnetotacticum, M58171; NIX bacterium, M94381; Piscirickettsia salmonis, X60783; Rhodobacter capsulatus, D16428; Rhodobacter sphaeroides, D16425; Rhodospirillum rubrum, D30778; Rickettsia prowazekii, M21789; Rickettsia rickettsii, M21293; Rickettsia typhi, M20499; Sphingomonas capsulata D16147; Sphingomonas paucimobilis, D13725; Wolbachia pipientis, X61768. The sequence for Holospora obtusa is maintained in the nucleotide sequence data base of the Ribosomal Data Base Project under accession number Hol.obtusa.

The 16S rDNA sequence of the NHP bacterium has been submitted to the EMBL and GenBank databases. The GenBank accession number for the NHP bacterium is $\mathrm{U} 65509$. 


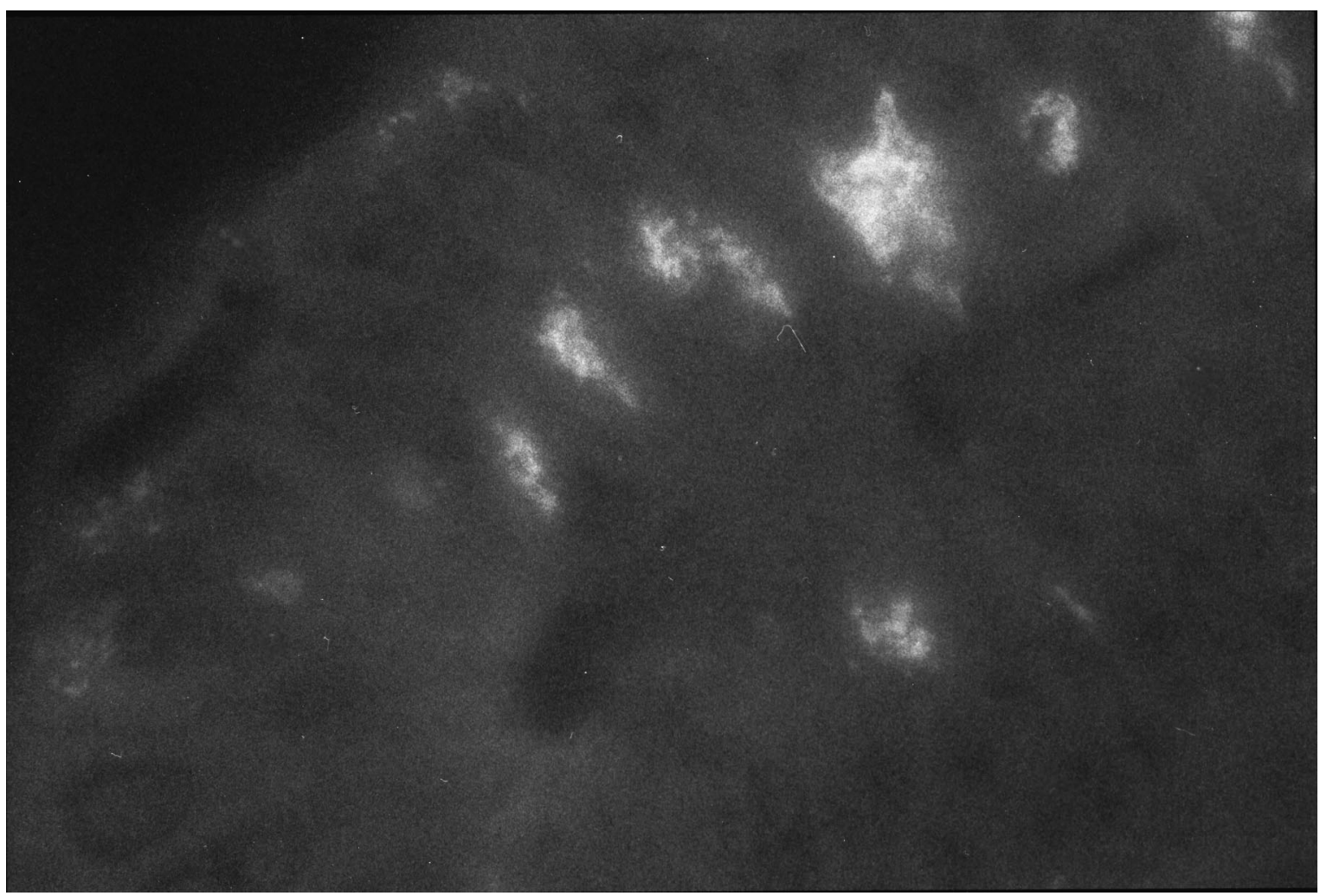

FIG. 2. Hepatopancreas of a Pacific white shrimp infected with the NHP bacterium. The figure demonstrates a positive fluorescent signal in numerous infected epithelial cells. Probe prV8 labeled with fluorescein isothiocyanate was used.

\section{RESULTS AND DISCUSSION}

Nearly the entire $16 \mathrm{~S}$ rDNA (1416 bases) of the NHP bacterium was amplified, cloned, and sequenced for phylogenetic placement of the organism. The 16S rDNA sequence of the NHP bacterium was compared 23 with those of members of the $\alpha$ subclass of the class Proteobacteria ( $\alpha$-Proteobacteria) and 4 members of the $\gamma$-Proteobacteria, and the similarity matrix for this comparison is shown in Table 3. A phylogenetic tree constructed from the similarity data by using the neighbor-joining method clearly demonstrates that the NHP bacterium is a member of the $\alpha$-Proteobacteria (Fig. 1). The association of the NHP bacterium with the $\alpha$-Proteobacteria is supported by the fact that this subdivision includes many bacteria that form intimate and often intracellular associations with eukaryotes $(34,43,44)$. Within the $\alpha$-Proteobacteria, the NHP bacterium forms a monophylotetic cluster with bacteria that have not been included in the four recognized subgroups $(\alpha-1, \alpha-2, \alpha-3$, and $\alpha-4)$ of the $\alpha$-Proteobacteria (36). The bacteria in this cluster include members of the family Rickettsiaceae (A. marginale, C. ruminatum, W. pipientis, E. sennetsu, $R$. typhi, $R$. prowazekii, and $R$. rickettsii), as well as the protozoal endosymbionts $C$. caryophila and $H$. obtusa. The NHP bacterium was most similar to C. caryophila $(87.4 \%)$ and $H$. obtusa $(84.1 \%)$ and slightly less similar to three Rickettsia species, $R$. prowazekii, $R$. typhi, and $R$. rickettsii (approximately $83.5 \%$ ).

In the present study, the NHP bacterium is shown to be most closely related to $C$. caryophila, a protozoal endosymbiont of the macronucleus of Paramecium caudatum. The association of the NHP bacterium with $C$. caryophila is intriguing, because several significant features are common to both organisms. As seen in the NHP bacterium, $C$. caryophila and its close relative
Holospora obtusa exhibit multiple distinct morphologic forms (29). In C. caryophila, these forms include a nonbright (as determined by phase-contrast microscopy) reproductive form and a larger, refractile, bright form (32). H. obtusa is known to have an infectious form, a replicative form, and an intermediate form (termed the activated infectious form) (15). However, C. caryophila is distinguished from the NHP bacterium and other killer endosymbionts because it produces refractile inclusions consisting of tightly coiled proteinaceous ribbons (33). These so-called R bodies have not been observed in the NHP bacterium.

A primary justification for pursuing phylogenetic classification of the NHP bacterium was to gain insight into its ecology and in vitro culture requirements. As phylogenetic categories are predictive, the information that is known about one organism can generally be applied to its relatives $(26,39)$. $C$. caryophila is described as an obligate bacterial endosymbiont, and nothing is known about its persistence outside the host paramecia (33). As was previously demonstrated for the NHP bacterium (13), C. caryophila can be purified by centrifugation but has not been cultivated on enriched media, and neither $C$. caryophila nor $H$. obtusa has been cultivated outside its host paramecium $(32,33)$. Although the association of the NHP bacterium with $C$. caryophila and $H$. obtusa is not informative with regard to in vitro culture requirements of the NHP bacterium, it may provide insight into the ecology of the organism in the pond environment. Epicommensal protozoans are common fouling agents that live on the cuticular surfaces, gills, and appendages of $P$. vannamei (11). Light infestations with these organisms are not associated with disease, and their presence is considered incidental (23). However, in view of the phylo- 


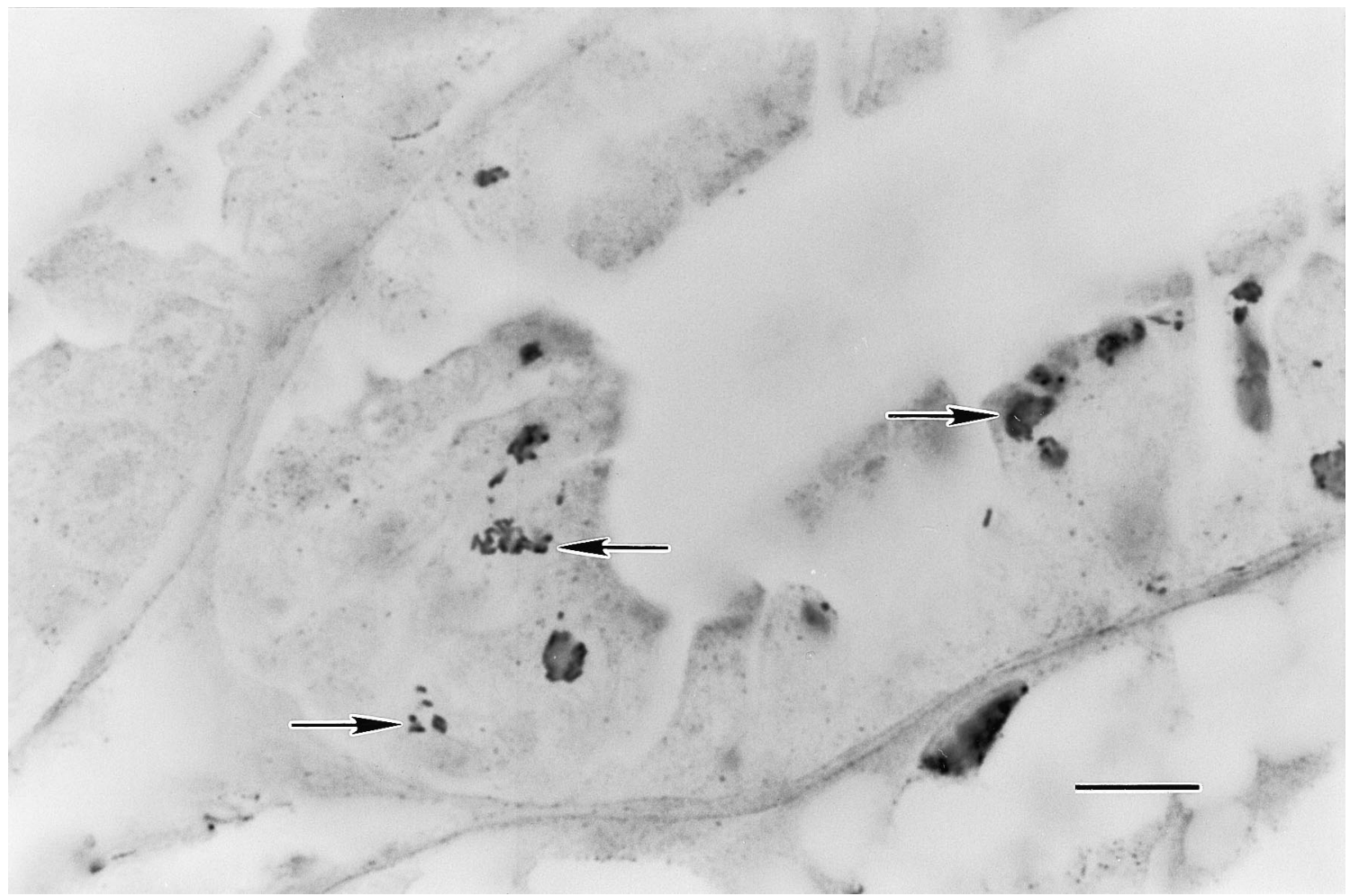

FIG. 3. Hepatopancreas of a Pacific white shrimp infected with the NHP bacterium. The specimen is the same as that depicted in Fig. 2. The intracellular bacteria (arrows) are evident. The Steiner and Steiner method was used. Bar, $10 \mu \mathrm{m}$.

genetic association of the NHP bacterium with an intracellular endosymbiont of protozoa, the possibility that the epicommensal protozoan harbors the NHP bacterium should be investigated.

The sequence analysis also demonstrated that the NHP bacterium is distinct from but related to Rickettsia spp. and their relatives. This intriguing association is bolstered by the facts that the NHP bacterium is an intracellular pathogen of a marine invertebrate and many of the rickettsias infect the midgut epithelia of their invertebrate vectors. However, the unique morphologic features of the NHP bacterium, inadequate knowledge about the life cycle of the organism, and the distant divergence of the NHP bacterium from phylogenetically classified organisms in the $\alpha$-Proteobacteria preclude placement of the NHP bacterium within a defined genus (9).

The absence of shrimp cell lines and inadequate knowledge about the complex growth requirements of the NHP bacterium have prevented in vitro cultivation by standard culture methods. In the absence of a pure culture of the NHP bacterium, a sucrose density gradient-enriched isolate served as the template DNA for the PCR amplification of 16S rDNA. General prokaryotic PCR primers that amplify the $16 \mathrm{~S}$ rDNA from a wide range of bacteria were used to amplify the 16S rDNA of the NHP bacterium (38). Although the enriched bacterial isolate was demonstrated to reproduce NHP in a previous study (13), the nonspecific primers could have amplified the $16 \mathrm{~S}$ rDNA of a bacterial contaminant. In this study, the source of the cloned 16S rDNA was authenticated to be the NHP bacterium by fluorescent in situ hybridization. In situ hybridization is the most direct way to link a $16 \mathrm{~S}$ rRNA sequence to a defined bacterial morphotype $(3,6,40)$. The sequence data generated from this study were analyzed, and oligonucleotide probes that hybridize to three different variable regions (V2,
V6, and V8) of the NHP bacterial 16S rRNA were designed and tested by in situ hybridization. The probes were compared with sequence data in the ribosomal database and detected no matches with less than three mismatched base pairs (25). Furthermore, all three manufactured oligonucleotide probes demonstrated a specific in situ hybridization signal from shrimp hepatopancreata that were infected with the NHP bacterium, thereby authenticating the origin of the cloned and sequenced 16S rDNA to the NHP bacterium (Fig. 2). The positive hybridization signal localized to the cytoplasm of hepatopancreatic epithelial cells that were demonstrated to be infected with the NHP bacterium by using homologous sections stained by the Steiner and Steiner method (Fig. 3) (14). No hybridization signal was obtained when the NHP-specific probes were hybridized to uninfected shrimp tissue, $P$. monodon tissue infected with a different rickettsia-like bacterium, and shrimp tissue infected with Vibrio spp. The shrimp infected with intracellular bacteria (NHP bacterium or $P$. monodon rickettsia-like organism), and tissues infected with Vibrio spp. demonstrated a positive hybridization signal when incubated with a eubacterial 16 S probe (19).

Although nucleic acid probes show promise in shrimp diagnostic pathologic testing (5), widespread use of fluorescent in situ hybridization in shrimp diagnostics is unlikely because of the autofluorescence of the many chitinous cuticular structures in shrimp. This background autofluorescence was avoided in the present study through the use of prosected hepatopancreata. Little or no autofluorescence was observed in the hepatopancreas, and the strong fluorescent signal readily discriminated infected from uninfected epithelial cells. Detection of the NHP bacterium with the $16 \mathrm{~S}$ rRNA fluorescent probes may, however, provide a means of determining the life cycle of the NHP bacterium outside the host epithelial cell. Such 
knowledge may be important in instituting avoidance mechanisms and thus preventing the widespread mortalities presently associated with NHP in cultured populations of $P$. vannamei.

\section{ACKNOWLEDGMENT}

This research was funded, in part, under grant H-8158 from the Texas Agriculture Experiment Station, Texas A\&M University System.

\section{REFERENCES}

1. Altschul, S. F., W. Gish, W. Miller, E. W. Myers, and D. J. Lipman. 1990. Basic local alignment search tool. J. Mol. Biol. 215:403-410.

2. Amann, R. I., L. Krumholtz, and D. A. Stahl. 1990. Fluorescent-oligonucleotide probing of whole cells for determinative, phylogenetic, and environmental studies in microbiology. J. Bacteriol. 172:762-770.

3. Amann, R. I., N. Springer, W. Ludwig, and K. H. Schleifer. 1991. Identification in situ and phylogeny of uncultured bacterial endosymbionts. Nature (London) 351:161-164.

4. Braun-Howland, E. B., S. A. Danielsen, and S. A. Nierzwicki-Bauer. 1991. Development of a rapid method for detecting bacterial cells in situ using $16 \mathrm{~S}$ rRNA-targeted probes. BioTechniques 13:928-933.

5. Bruce, L. D., R. M. Redman, D. V. Lightner, and J. R. Bonami. 1993. Application of gene probes to detect a penaeid shrimp baculovirus in fixed tissue using in situ hybridization. Dis. Aquat. Org. 17:215-221.

6. Delong, E. F., G. S. Wickham, and N. R. Pace. 1989. Phylogenetic stains: ribosomal RNA-based probes for the identification of single cells. Science 243:1360-1362.

7. Dewhirst, F. E., B. J. Paster, and P. L. Bright. 1989. Chromobacterium, Eikenella, Kingella, Neisseria, Simonsiella, and Vitreoscilla species comprise a major branch of the beta group Proteobacteria by $16 \mathrm{~S}$ ribonucleic acid sequence comparison: transfer of Eikenella, and Simonsiella, to the family Neisseriacae (emend.). Int. J. Syst. Bacteriol. 40:426-433.

8. Dewhirst, F. E., C. Seymour, B. J. Fraser, and J. G. Fox. 1994. Phylogeny of Helicobacter isolates from bird and swine feces and description of Helicobacter pametensis sp. nov. Int. J. Syst. Bacteriol. 44:553-560.

9. Drancourt, M., and D. Raoult. 1994. Taxonomic position of the Rickettsiae: current knowledge. FEMS Microbiol. Rev. 13:13-24.

10. Edman, J. C., J. A. Kovaks, H. Masur, D. V. Santi, H. J. Elwood, and M. L. Sogin. 1988. Ribosomal RNA sequence shows Pneumocystis carini to be a member of the fungi. Nature (London) 334:519-522.

11. Foster, C. A., T. J. Sarphie, and W. E. Hawkins. 1978. Fine structure of the peritrichous ectocommensal Zoothamnium sp. with emphasis on its mode of attachment to penaeid shrimp. J. Fish Dis. 1:321-335.

12. Fox, G. E., E. Stackebrandt, R. B. Hespel, J. Gibson, J. J. Maniloff, T. A. Dyer, R. S. Wolfe, W. E. Balch, R. S. Tanner, L. J. Magrum, L. B. Zablem, R. Blackmore, R. Gupta, L. Bonen, B. J. Lewis, D. A. Stahl, K. R. Luenhersen, K. N. Chen, and C. R. Woese. 1980. The phylogeny of prokaryotes. Science 209:457-463.

13. Frelier, P. F., J. K. Loy, and B. Kruppenbauch. 1992. Transmission of necrotizing hepatopancreatitis in Penaeus vannamei. J. Invertebr. Pathol. 61:44-48.

14. Frelier, P. F., R. F. Sis, T. A. Bell, and Lewis. 1992. Microscopic and ultrastructural studies of necrotizing hepatopancreatitis in Pacific white shrimp (Penaeus vannamei) cultured in Texas. Vet. Pathol. 29:269-277.

15. Gortz, H.-D., S. Lellig, O. Miosga, and M. Wiemann. 1990. Changes in fine structure and polypeptide pattern during development of Holospora obtusa, a bacterium infecting the macronucleus of Paramecium caudatum. J. Bacteriol. 172:5664-5669.

16. Humason, G. L. 1979. Special procedures I, p. 463. In D. L. Humason (ed.), Animal tissue techniques. W. H. Freeman \& Co., San Francisco.

17. Johnson, S. K. 1989. Digestive gland manifestations, p. 16. In S. K. Johnson (ed.), Handbook of shrimp diseases, Sea Grant College Program, Texas A\&M University, Galveston, Tex.

18. Jukes, T. H., and C. R. Cantor. 1969. Evolution of protein molecules, p. 21-132. In H. N. Munro (ed.), Mammalian protein metabolism, vol. 3. Academic Press, Inc., New York.

19. Jurtshuk, R. E., M. Blick, J. Bresser, G. E. Fox, and P. Jurtshuk. 1992. Rapid in situ hybridization technique using 16S rRNA segments for detection and differentiating the closely related gram-positive organisms Bacillus polymyxa and Bacillus macerans. Appl. Environ. Microbiol. 58:2571-2578.

20. Kerk, D., A. Gee, F. E. Dewhirst, A. S. Drum, and R. A. Elston. 1992 Phylogenetic placement of nuclear inclusion X (NIX) into the gamma sub- division of Proteobacteria on the basis of $16 \mathrm{~S}$ ribrosomal RNA sequence comparisons. Syst. Appl. Microbiol. 42:439-445.

1. Krol, R. M., W. E. Hawkins, and R. M. Overstreet. 1992. Rickettsial an mollicute infections in hepatopancreatic cells of cultured Pacific white shrimp (Penaeus vannamei). J. Invertebr. Pathol. 57:362-370.

22. Kumar, S., K. Tamura, and M. Nei. MEGA: molecular evolutionary genetics analysis, version 1.0. The Pennsylvania State University, University Park, Pa.

23. Lightner, D. V. 1988. Protozoal fouling diseases of penaeid shrimp, p. 76-79. In C. J. Sindermann and D. V. Lightner (ed.) Disease diagnosis and control in North American marine aquaculture. Elsevier Science Publishing, Inc., New York.

24. Lightner, D. V., R. M. Redman, and J. R. Bonami. 1992. Morphologica evidence for a single bacterial etiology in Texas necrotizing hepatopancreatitis in Penaeus vannamei (Crustacea: Decapoda). Dis. Aquat. Org. 13:235239.

25. Maidak, B. L., N. Larsen, M. J. McCaughey, R. Overbeek, G. J. Olsen, K. Fogel, J. Blandy, and C. R. Woese. 1994. The Ribosomal Database Project. Nucleic Acids Res. 22:3485-3489.

26. Olsen, G. J., D. J. Lane, S. J. Giovannoni, N. R. Pace, and D. A. Stahl. 1986. Microbial ecology and evolution: a ribosomal RNA approach. Annu. Rev. Microbiol. 40:337-365.

27. Olsen, G. J., and C. R. Woese. 1993. Ribosomal RNA: a key to phylogeny. FASEB J. 7:113-123.

28. Paster, B. J., and F. E. Dewhirst. 1988. Phylogeny of campylobacters, woliellas, Bacteroides gracilis, and Bacteroides ureolyticus by $16 \mathrm{~S}$ ribosomal ribonucleic acid sequencing. Int. J. Syst. Bacteriol. 38:56-62.

29. Preer, J. R., and L. B. Preer. 1982. Revival of names of protozoal endosymbionts and proposal of Holospora caryophila nom. nov. Int. J. Syst. Bacteriol. 32:140-141

30. Relman, D. A., J. S. Loutit, T. M. Schmidt, S. Falkow, and L. S. Tompkins. 1990. The agent of bacillary angiomatosis. An approach to the identification of uncultured pathogens. N. Engl. J. Med. 323:1573-1580.

31. Saitou, N., and M. Nei. 1987. The neighbor-joining method: a new method for reconstructing phylogenetic trees. Mol. Biol. Evol. 4:404-425.

32. Schmidt, H. J., H.-D. Gortz, and R. L. Quackenbush. 1987. Caedibacter caryophila sp. nov., a killer symbiont inhabiting the macronucleus of Paramecium caudatum. Int. J. Syst. Bacteriol. 37:459-462.

33. Springer, N., W. Ludwig, R. Amann, H. J. Schmidt, H.-D. Gortz, and K.-H Schleifer. 1993. Occurrence of fragmented 16S rRNA in an obligate bacterial endosymbiont of Paramecium caudatum. Proc. Natl. Acad. Sci. USA 90: 9892-9895.

34. Stackebrandt, E., R. G. E. Murray, and H. G. Truper. 1988. Proteobacteria classis nov., a name for the phylogenetic taxon that includes the "purple bacteria and their relatives." Int. J. Syst. Bacteriol. 38:321-325.

35. Stahl, D. A., and R. Amann. 1991. Development and application of nucleic acid probes, p. 205-248. In E. Stackebrandt and M. Goodfellow (ed.), Nucleic acid techniques in bacterial systematics. John Wiley \& Sons, Inc., New York

36. Takeuchi, M., H. Sawada, H. Oyaizu, and A. Yokota. 1994. Phylogenetic evidence for Sphingomonas and Rhizomonas as nonphotosynthetic members of the alpha-4 subclass of the Proteobacteria. Int. J. Syst. Bacteriol. 44:308314.

37. Tamura, A., U. Urakami, and T. Tsuruhara. 1982. Purification of Rickettsia tsutsugamushi by Percoll density gradient centrifugation. Microbiol. Immunol. 26:321-328

38. Weisburg, W. G., S. M. Barns, D. A. Pelletier, and D. J. Lane. 1991. 16 S ribosomal DNA amplification for phylogenetic study. J. Bacteriol. 173:697703.

39. Weisburg, W. G., T. P. Hatch, and C. R. Woese. 1986. Eubacterial origin of chlamydiae. J. Bacteriol. 167:570-574.

40. Wetmer, J. G. 1991. DNA probes: applications of the principles of nucleic acid hybridization. Crit. Rev. Biochem. Mol. Biol. 26:227-259.

41. Wilson, K. H., R. Blitchington, R. Frothingham, and J. A. P. Wilson. 1991 Phylogeny of the Whipple's-disease-associated bacterium. Lancet 338:474475 .

42. Wilson, K. H., R. H. Blitchington, and R. G. Greene. 1990. Amplification of bacterial $16 \mathrm{~S}$ ribosomal DNA with polymerase chain reaction. J. Clin. Microbiol. 28:1942-1946.

43. Woese, C. R. 1987. Bacterial evolution. Microbiol. Rev. 51:221-227.

44. Woese, C. R., E. Stackebrandt, W. G. Weisberg, B. J. Paster, M. T. Madigan, V. J. Fowler, C. M. Hahn, P. Blantz, R. Gupta, K. H. Nealson, and G. E. Fox 1984. The phylogeny of the purple bacteria: the alpha subdivision. Syst. Appl. Microbiol. 5:315-326. 